\title{
Using data to target and scale-up girls' support programs and child marriage prevention
}

The Evidence Project

Follow this and additional works at: https://knowledgecommons.popcouncil.org/departments_sbsr-rh

Part of the Demography, Population, and Ecology Commons, Family, Life Course, and Society Commons, International Public Health Commons, Maternal and Child Health Commons, and the Sociology of Culture Commons How does access to this work benefit you? Let us know!

\section{Recommended Citation}

"Using data to target and scale-up girls' support programs and child marriage prevention," Policy brief. Washington, DC: Population Council, The Evidence Project, 2017. 


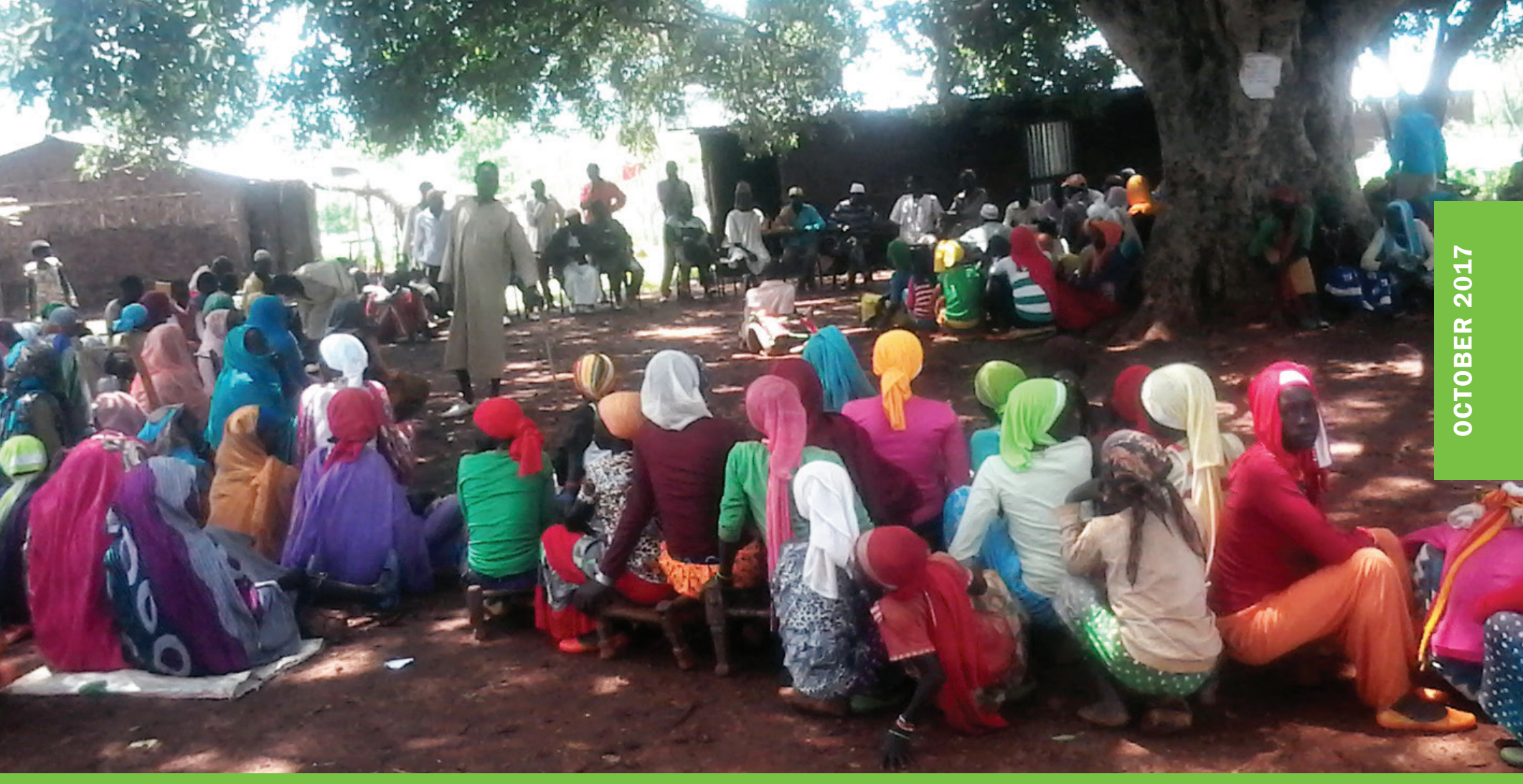

POLICY BRIEF

\section{Using Data to Target and Scale-Up Girls' Support Programs and Child Marriage Prevention}

Of the women in the world today, approximately $250,000,000$ were married before the age of 15 , and another approximately 450,000,000 were married between the ages of 15 and 18 (United Nations Children's Fund 2014). Though child marriage is declining globally, it is estimated that over 100 million girls under age 18 will be married in the next decade (UNICEF 2015). Risk for child marriage varies, even within a country, with risk factors including things such as poverty, ethnic group, and rural residency. The detrimental effects of child marriage, however, are universal: girls who are married as children lose their childhood and often become socially isolated; have limited educational and employment opportunities; and, being young and lacking skills to negotiate safer sex, are vulnerable to early pregnancy (and its many associated negative consequences) and HIV and other sexually transmitted infections. Child marriage is most prevalent in South Asia and sub-Saharan Africa. Though median age at first marriage has been on the rise over the past three decades, Ethiopia falls in the top 10 countries with the highest rates of child marriage: among 20-49-year-old women, 58 percent were married or in union before the age of 18 .

Despite this, few programs to prevent child marriage have been implemented and most of those remain small-scale and unevaluated. A 2012 review of child marriage interventions in developing countries found that the most effective approaches in delaying child marriage were those that offered incentives, such as conditional cash transfers or provision of school materials, and those that empower girls directly through interventions such as girls' groups and training (Lee-Rife et al 2012). 


\section{PILOTING BERHANE HEWAN}

The Berhane Hewan program in Ethiopia (meaning 'Light for Eve' in Amharic) was one of the earliest to test child marriage prevention interventions in subSaharan Africa. The program, a partnership between the Ethiopian government and the Population Council, was designed to prevent child marriage and support already married girls. The initial design of the intervention, which ran from 2004-2006, included four components:

1. Community conversations to address social norms related to child marriage

2. Provision of school supplies to encourage retention in school and thereby protect girls from marriage

3. A conditional asset transfer, promising girls and their families a goat if she remains unmarried and in school

4. Married girls' groups led by adult female mentors including lessons on life skills, family planning and other reproductive health topics.

After two years of the intervention, girls ages 10 to 14 in the Berhane Hewan site were 90 percent less likely to be married and three times more likely to be in school, compared to girls in the control area (Erulkar and Muthengi, 2009).

Berhane Hewan Project Sites, Beneshangul-Gumuz Region, Ethiopia

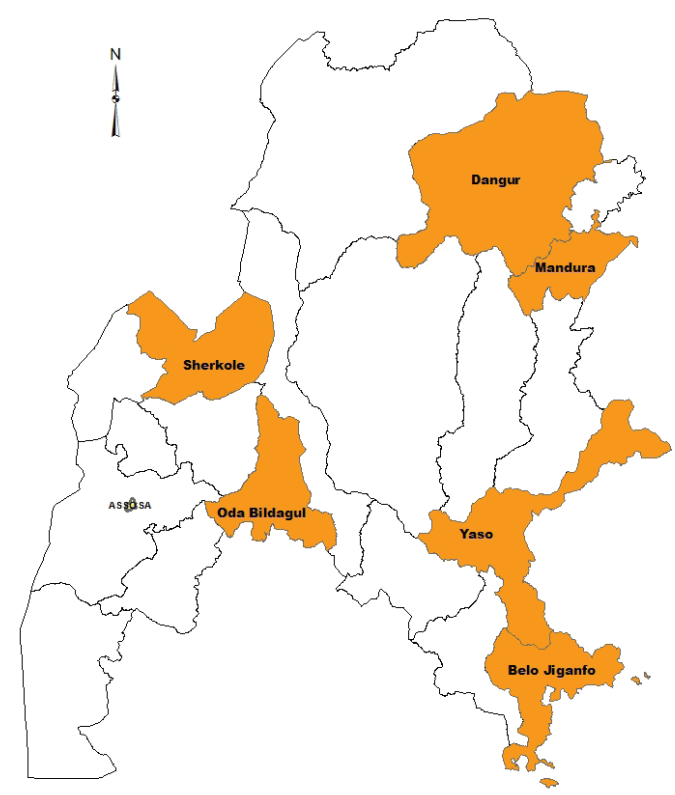

BOX 1

The scale-up study also provided information on how to refine and improve the design and implementation of child marriage prevention programs, including:

- Identify and target specific geographical locations at the sub-regional level where child marriage is most prevalent, to target investment and intervention in the highest burden locations

- Pay attention to coverage of interventions on the ground, particularly in rural communities where many sites are remote, inaccessible and require hours of travelling by foot or donkey to ensure the interventions reach a large proportion of the eligible girls at risk of early marriage.

Testing Berhane Hewan for scale-up: Despite successful findings from the intervention, local partners questioned the feasibility of scaling-up Berhane Hewan given its multi-component design and lack of costing information (Muthengi and Erulkar, 2011). As a result, the Population Council, with support from USAID, designed a follow-on study (2010-2016) to test if simplified, more easily scaledup, Berhane Hewan interventions could still be effective in delaying marriage. Each original Berhane Hewan intervention was implemented in a different geographic area to identify the specific impact of a minimum-basic package of interventions and to collect costing data. The study found that providing school supplies to younger adolescents (ages 12 to 14 ) and conditional assets in the form of chickens to older adolescents (ages 15 to 17) was effective in delaying marriage in rural Ethiopia. The cost of providing these school supplies and conditional assets (chickens) was USD \$20 and USD \$32, respectively, per girl per year (Erulkar, Girmay and Weissman 2017).

\section{IDENTIFYING THE NEED: THE CHILD CENSUS TOOL}

For scale-up to be effective, the areas with the highest rates of child marriage need to be identified for program expansion. To aid in identifying sub-regional locations with the highest prevalence of girls who are out of school and/or married before age 18, the 
Population Council developed a rapid, communitylevel assessment tool, the 'Child Census.' This rapid tool assesses the status of both girls and boys in communities where it is undertaken, and allows programmers to compare the status of girls to boys in project communities to create a tangible, data-driven justification for programmatic focus on girls. It also contributes, generally, to evidence-driven programming for children and youth.

The Child Census collects information on children as young as six to provide data on the timing of school entry in project communities, allowing program managers to gauge when a child is 'off-track' in their schooling. Data from the Child Census allows identification of locations

\section{FIGURE 1. PERCENTAGE OF YOUNG PEOPLE AGED 15 TO 24 WHO NEVER ATTENDED SCHOOL}

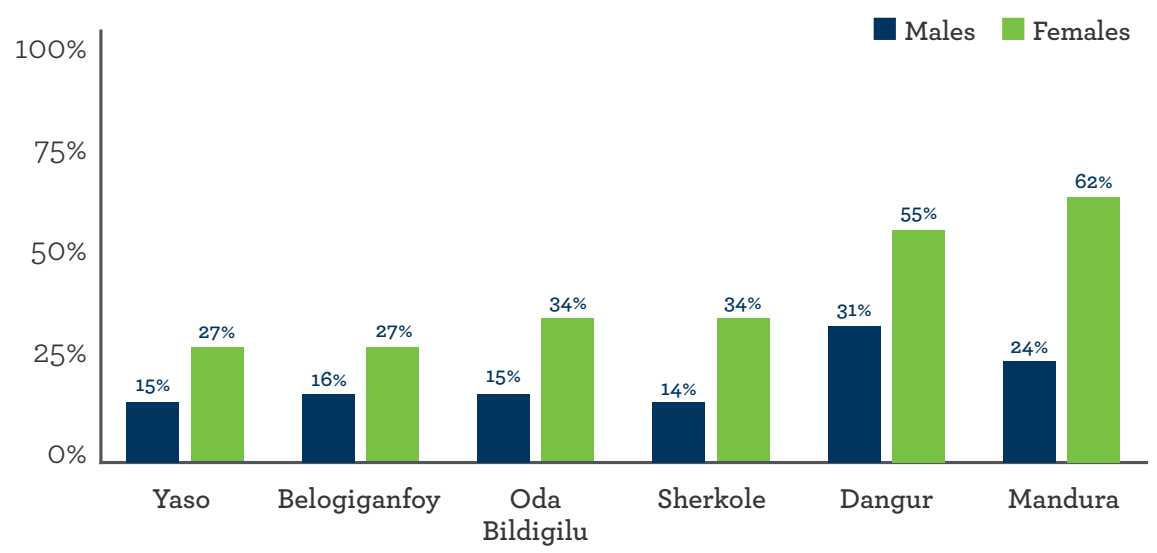

Woreda

Figure 2. PERCENTAGE OF YOUNG PEOPLE AGED 15 TO 24 WHO WERE MARRIED BY AGE 18

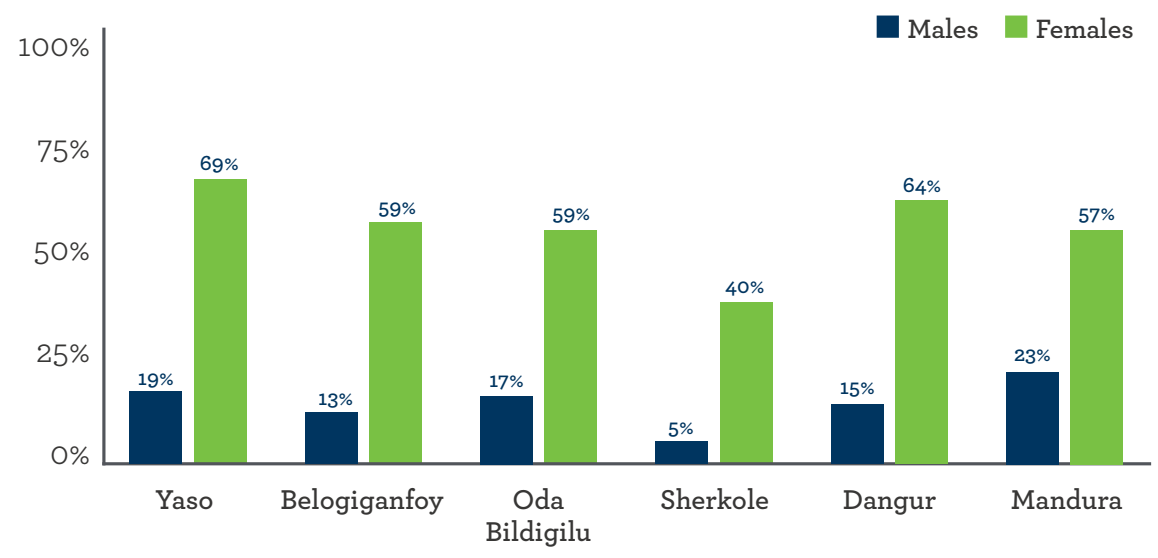

Woreda where the greatest numbers of girls are out-of-school and/or married, serves as a rapid baseline survey for eventual project interventions, and enumerates the universe of eligible girls in the project communities.

\section{LEARNING ABOUT THE STATUS OF CHILDREN THROUGH THE CHILD CENSUS}

As part of the Berhane Hewan scale up study, the Population Council used the Child Census tool to identify project communities with data collected from 50,572 boys and girls ages 6 to 24 in six woredas/ districts and 63 kebeles, the lowest administrative unit in Ethiopia. The Child Census data demonstrated considerable variability in the status between girls and boys, as well as across woredas and kebeles. For example, 62 percent of females ages 15 to 24 in Mandura woreda had never attended school, compared to 27 percent of females in Yaso woreda (Figure 1).

Child Census data confirmed that a significant proportion of young women were married as children (i.e. before age 18; Figure 2).

These and other data from the Child Census demonstrate the disparity between girls and boys, thus reinforcing the decision to focus on interventions for girls. Kebeles selected for project scale-up had at least 20 percent of girls ages 10 to 14 out-of-school or at least 20 percent of girls ages 12 to 17 already married.

\section{SCALING-UP BERHANE HEWAN}

In 2016, based on results from the Child Census, the Population Council and the Regional Bureau of Women and Children selected and began to support the scale-up of Berhane Hewan interventions in rural Benishangul-Gumuz Region, Ethiopia.

1 The age range of children can be adjusted based on the interests of program implementers. 
The region has the second highest prevalence of early child marriage in Ethiopia (22 percent of girls are married before age 15), yet few initiatives have been undertaken in the region. During this phase, evidencebased approaches from the earlier studies to address child marriage will be scaled up, including offering school supplies to younger girls (12 to 14$)$ and solar powered lights to older girls (15 to 17 ), conditioned upon girls remaining unmarried during the program. In response to community needs and feasibility, the offering for the 15-17 year-old girls changed from chickens in the original study to a solar powered light.

In addition to identifying the areas of greatest need and serving as baseline data, Child Census data enables monitoring of the percentage of eligible girls who registered for the schemes. For example, in Belogiganfoy woreda, an estimated 95 percent of eligible 12-to-14- year-olds registered for the scheme, compared to 61 percent of 15-to-17-year-olds. Greater participation of younger girls compared to older girls is consistent with earlier project experience in Amhara region.

To date, this phase of the child marriage prevention project has enrolled nearly 5,000 girls. The Child Census has been a critical tool for identifying communities to receive the intervention and for collecting monitoring data during implementation. In mid-2018, the Child Census methodology will be used to measure changes in the prevalence of child marriage and school attendance. Berhane Hewan demonstrates how studies can build upon themselves to generate improved and contextually-appropriate evidence that answers questions of key programmatic and policy importance.

\section{REFERENCES}

United Nations Children's Fund. (2014). Ending Child Marriage: Progress and prospects. New York: UNICEF.

Erulkar, A., and Muthengi, E. (2009). Evaluation of Berhane Hewan: A program to delay marriage in rural Ethiopia. International Perspectives on Sexual and Reproductive Health, 35 (1), 6-14.

Erulkar, A., Medhin, G., and Weissman, E. (2017). The impact and cost of child marriage prevention interventions in three African settings. New York: Population Council, June.
Muthengi, E., and Erulkar A. (2011). Building programs to address child marriage: The Berhane Hewan experience in Ethiopia. Addis Ababa, Ethiopia: Population Council, November.

Lee-Rife, S., Malhotra, A., Warner, A., and Glinski, A. (2012). What Works to Prevent Child Marriage: A Review of the Evidence. Studies in Family Planning, 43 (4), 287-303.

\section{THE EVIDENCE PROJECT}

Population Council 4301 Connecticut Ave. NW Washington, DC 20008 tel: +2022379400 evidenceproject@popcouncil.org

\section{CONTRIBUTORS}

Annabel Erulkar

Kate Gilles

Aparna Jain

Robin Keeley

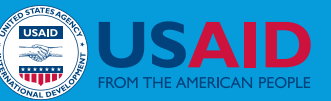

The Evidence Project is made possible by the generous support of the American people through the United States Agency for International Development (USAID) under the terms of cooperative agreement no. AID-OAA-A-13-00087. The contents of this document are the sole responsibility of the Evidence Project and Population Council and do not necessarily reflect the views of USAID or the United States Government.

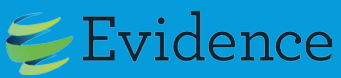

The Evidence Project uses implementation science-the strategic generation, translation, and use of evidence-to strengthen and scale up family planning and reproductive health programs to reduce unintended pregnancies worldwide. The Evidence Project is led by the Population Council in partnership with INDEPTH Network, International Planned Parenthood Federation, PATH, Population Reference Bureau, and a University Research Network.

Suggested Citation: 2017. “Using Data to Target and Scale-Up Girls' Support Programs and Child Marriage Prevention,” Policy Brief. Washington, DC: Population Council, The Evidence Project.

(c) 2017 The Population Council, Inc.

For more information, contact: Annabel Erulkar, Country Director, Population Council Ethiopia, 